\title{
The deterioration of Circular Mausoleum, Roman Necropolis of Carmona, Spain
}

Juan C. Cañaveras ${ }^{\mathrm{a}}$, Angel Fernandez-Cortes ${ }^{\mathrm{b}, \mathrm{c}}$, Javier Elez ${ }^{\mathrm{d}}$, Soledad Cuezva ${ }^{\mathrm{b}, \mathrm{c}}$, Valme Jurado ${ }^{\mathrm{e}}$, Ana Zelia Miller ${ }^{\mathrm{e}}$, Miguel A. Rogerio-Candelera ${ }^{\mathrm{e}}$, David Benavente ${ }^{\mathrm{a}}$, Mariona Hernandez-Marine ${ }^{f}$, Cesareo Saiz-Jimenez ${ }^{\mathrm{e}, *}$, Sergio Sanchez-Moral ${ }^{\mathrm{b}}$

aDepartamento de Ciencias de la Tierra y del Medio Ambiente, Universidad de Alicante, 03080 Alicante, Spain

${ }^{b}$ Museo Nacional de Ciencias Naturales, MNCN-CSIC, Jose Gutierrez Abascal 2, 28006 Madrid, Spain

${ }^{\circ}$ Geomnia Natural Resources SLNE, 28003 Madrid, Spain

${ }^{d}$ Departamento de Paleontologia, Universidad Complutense, 28040 Madrid, Spain

eInstituto de Recursos Naturales y Agrobiologia, IRNAS-CSIC, Avenida Reina Mercedes 10, 41012 Sevilla, Spain

${ }^{\mathrm{f}}$ Facultad de Farmacia, Universidad de Barcelona, 08028 Barcelona, Spain

\section{ABSTRACT}

The Circular Mausoleum in the Roman Necropolis of Carmona was carved on a calcarenite sequence in an ancient quarry located in the town of Carmona, Southern Spain. This rock-cut tomb, representative of Roman burial practices, currently suffers from serious deterioration. A detailed survey over several years permitted the identification of the main tomb's pathologies and damaging processes, which include loss of material (scaling, flaking, granular disintegration), surface modifications (efflorescences, crusts and deposits) and extensive biological colonization. The results obtained in this study indicated that anthropogenic changes were largely responsible and enhanced the main alteration mechanisms observed in the Circular Mausoleum. Based on the deterioration diagnosis, effective corrective actions were proposed. This study shows that any conservation intervention in the interior of the tomb should be preceded by accurate in situ measurements and laboratory analyses to ascribe the source of the deterioration damages and thus designing effective treatments.

*Corresponding author at: Instituto de Recursos Naturales y Agrobiologia, IRNASCSIC, Avenida Reina Mercedes 10, 41012 Sevilla, Spain

E-mail address: saiz@irnase.csic.es

Preprint submitted to Elsevier 


\section{Introduction}

The first tomb of a Roman Necropolis in the area of Carmona (province of Seville, Spain) was accidentally discovered in 1830 (Rada y Delgado, 1885; Maier Allende, 1999) although a few more tombs were exhumed between 1868 and 1869. These tombs were plundered until the archaeological excavations started in 1882 . This necropolis, located in the town of Carmona represents one of the most significant Roman burial sites in Southern Spain, and was in use during the 1st and 2nd centuries AD. Initially, the necropolis was used as quarry from which stone blocks were extracted and used for building construction. The quarry was then abandoned and reused as necropolis due to the workability of the rock.

The Necropolis has suffered numerous and extensive interventions since its discovery. The first one was the adaptation of the necropolis for visits in 1885, including the construction of a trail, and planting of trees and gardens around the tombs. Nowadays this garden is considered one of the most deteriorating factors from the end of the 19th century until the end of the 20th century, because it affected the conservation of the tombs due to continuous irrigation and consequent percolation of water inside the tombs, in addition to the damage caused by roots (Benavente et al., 2011; Fernandez-Cortes et al., 2013).

Taking into account the cultural, artistic and religious importance of the Necropolis of Carmona, its preservation and conservation are a major issue, both from cultural and economic points of view. This importance emphasises the need to define accurate and sustainable intervention protocols based on a deep understanding of the environmental and/or anthropogenic-induced deterioration processes. The design of effective monument preservation and/or conservation strategies should be based on exhaustive in situ surveys and laboratory investigations (Heinrichs and Fitzner, 2000).

The main aim of this work consisted in the assessment of the conservation state of the Circular Mausoleum rock-cut tomb, including the identification of the main deteriorating agents. In addition, an intervention proposal for the preservation of the Circular Mausoleum was presented.

\section{Methodology}

\subsection{Site description}

The Necropolis of Carmona comprises a large number of tombs (about 600) excavated in a $30 \mathrm{~m}$-thick Neogene sedimentary sequence. It is composed of decimeter-thick beds of poorly-sorted massive biocalcarenites (Fig. 1A,B). These are separated by lutitic and/or marly beds, ranging from millimeters to few centimeters thick and they are mostly discontinuous. This calcareous series is organized into four sequences, which in turn are divided into seven sub-sequences 
or lithological units comprising the geological mapping of the site. Most tombs were collective mausoleums consisting of underground chambers accessed by a shaft.

The Circular Mausoleum is rectangular with a barrel vault and eleven niches carved on the walls (Fig. 1C). It is a small tomb, with less than $3 \mathrm{~m}$ of vertical development. The long side of the chamber has a $\mathrm{N} 270^{\circ}$ direction, with the entrance (a shaft) facing west. The tomb gets flooded by direct rainfall input through the shaft. At present, the walls and ceiling of the tomb are heavily deteriorated; only $50-60 \%$ of the inner surface is covered by mortars and stuccos.

\subsection{Materials characterization and alteration products}

Circular Mausoleum building materials (host rock, mortars and stuccos) and alteration products (crusts, salt efflorescence and microbial colonization) were sampled and analysed. The mineralogical composition was analysed by powder Xray diffraction in a Philips $\mathrm{PW}-1710 / 00$ diffractometer using the $\mathrm{Cu} \mathrm{Ka}$ radiation with a Ni filter and a setting of $40 \mathrm{kV}$ and $40 \mathrm{~mA}$. Data were collected and interpreted using the XPowder software package. The qualitative search-matching procedure was based on the ICDD-PDF2 database. A detailed study of the pore structure of host-rock, mortars and stuccos was carried out using nitrogen adsorption techniques, which provide specific surface area (SSA), volume fraction and pore size distribution in the micro-mesoporosity pore fraction. The determination of the SSA was carried out through the BET method in the relative pressure interval P/PO $=0.05-0.2$ by using an Autosorb-6 Quantachrome apparatus.

To assess deterioration phenomena, the Circular Mausoleum was studied at the mesoscale by means of in situ description of weathering forms. Mapping of weathering forms were performed to register and evaluate the state of conservation on selected plans of the interior of the tomb. ICOMOS ICS glossary (2008) was used for weathering form terminology.

\subsection{Micro-environmental and climatic monitoring system}

A micro-environmental monitoring system was installed inside the Circular Mausoleum to record the microclimate. The Data Acquisition System consisted of a HOBO-U12 data logger, with a set of four sensors to record air temperature, air relative humidity, temperature of the rock surface and light intensity. These parameters were recorded every 15 min from June 2007 to April 2009. In addition, it was used a HOBO Pro v2 data logger with built-in temperature and relative humidity sensors for air measurements (Onset Computer Corporation, Bourne, MA, USA). Air temperature was measured with an accuracy of $\pm 0.2^{\circ} \mathrm{C}$ over $0^{\circ}$ to $50^{\circ} \mathrm{C}$. The relative humidity sensor operated over a $\mathrm{RH}$ range from 0 to $100 \%$ with a minimum accuracy of $\pm 3.5 \%$ (above $95 \%$ ). The rock-surface temperature was measured using a two thermocoupled sensor TMC20-HD (Onset Computer 
Corporation), with an accuracy of $\pm 0.25^{\circ}$ at $20^{\circ} \mathrm{C}$, inserted up to $2 \mathrm{~cm}$ inside the 2,5V (Apogee Instruments, Logan, UT, USA) calibrated to measure total shortwave radiation up to $1100 \mathrm{~W} \mathrm{~m}-2$ (full sunlight) with an absolute accuracy of $\pm 5 \%$ and repeatability of $\pm 1 \%$.

Outdoor climate was measured by means of a weather station (HOBO Weather Station HWS, Onset Computer Corporation) which included a tipping-bucket rain gauge (S-RGB model) for rainfall measurements, a barometer S-BPA-CM10 providing average barometric pressure for each logging interval and a 12-bit Smart Sensor (STHB model from Onset Computer Corporation) to measure the relative humidity and air temperature with an accuracy of $\pm 0.2^{\circ} \mathrm{C}$ over $0^{\circ}$ to $50^{\circ} \mathrm{C}$, and $\pm 2.5 \%$ from $10 \%$ to $90 \% \mathrm{RH}$, to a maximum of $+/-3.5 \%$ (above $95 \%$ ).

\subsection{Light flux and surface temperature measurements in the interior of the Tomb}

In order to define the spatial evolution of the daily and annual cycle of the perceived power of light and temperature in the inner surface of the tomb, measurements of both light flux and surface thermal radiation in the internal (nonexposed) areas of the Circular Mausoleum were achieved.

Luminous flux measurements were obtained with a digital light meter ISO-TECH, with a measuring range from 0.01 lux to $0.1 \mathrm{Klux}$, and an accuracy of $+/-3 \%$ (calibrated to standard incandescent lap at colour temperature of $2856 \mathrm{~K}$ ). The photodetector is a Silicon Photo Diode with a spectral response filter. Seventy six different sampling points and four different campaigns were performed: 1) on the evening of June 11,$2008 ; 2$ ) on the morning of June 12,$2008 ; 3$ ) on the evening of October 2, 2008; and 4) on the morning of January 28, 2009 (Fig. 2). These measurements were conducted close to the summer (sampling campaigns 1 and 2) and winter solstices (sampling campaign 4), and to equinox (sampling campaign 3). This roughly covered a whole year of luminous flux and allowed daily comparisons.

The surface temperature was measured with a digital Pyrometer Trotec model TP8, with contact-free infrared surface thermometer. The sensor registers the thermal radiation emitted or reflected by the surface, with a correction parameter relative to the radiation emitted by each specific material. In this case, a standard emission factor of 0.95 for the studied materials was estimated. The measurement ranged from -50 to $+1000^{\circ} \mathrm{C}$, with a resolution of $0.1^{\circ} \mathrm{C}$, a precision of $+/-1.5 \%$ (in the range from -20 to $+200{ }^{\circ} \mathrm{C}$ ), an optical precision of $50: 1$, a spectral sensitivity of 6 14 microns and a minimum measure surface of $6 \mathrm{~mm}$. In this case, six different campaigns were performed in the same 76 sampling points mentioned before (on the evening of October 18, 2007; on the evening of June 11, 2008; on the morning of June 12, 2008; on the morning and evening of October 2, 2008; and the morning of January 28, 2009). These sampling campaigns were performed close to the 
summer solstice, three close to the equinox and another one close to the winter solstice.

A simple tomb 3D Computer Aided Design Model (CAD) was obtained from topographic information and completed together with detailed schemes (Bendala, 1976), and then integrated in a 3D Geographic Information System (GIS) environment. This was the spatial context used to locate a georeferenced database of the sampling points and measurements. With these data, and applying a colour ramp depending on the individual values of light intensity and temperature, a schematic representation of the 3D evolution of both parameters in the interior of the tomb was achieved.

In order to calculate the duration of direct insolation in the Circular Mausoleum, a $3 \mathrm{D}$ model of the main entrance of the tomb was obtained from existing topographies. From this elevation model, the duration of insolation in hours for the solstices and equinoxes were calculated (following algorithm and workflow from Dubayah and Rich, 1995, 1996; Fu and Rich 1999, 2000). These data allowed interpreting the spatial variation of the duration of insolation in the entrance area over an annual cycle and compare this with temperature and luminous flux measured in the interior of the tomb. Resulting spatial model in raster format was draped over 3D topographic model of the entrance of the tomb to evidence the spatial relations of the obtained duration of insolation values relative to the shape of the entrance.

\subsection{Identification of phototrophic microorganisms}

A sampling survey was conducted in May 2009 under the supervision of the Spanish authorities in charge of the Necropolis of Carmona. Six sampling areas exhibiting green biofilms were studied. These biofilms were gently scrapped, using a sterilized scalpel, and placed in sterile tubes for identification of phototrophic microorganisms by direct examination under light microscopy and culture methods.

Samples were inoculated on Petri plates containing solid BG11 culture medium and incubated at $20^{\circ} \mathrm{C}$ for four weeks. Features of individual species were observed using light microscopy equipped with a photographic camera. Taxonomic identification was based on morphological characters of colonies growing on the agar plates using identification keys (Ettl and Gärtner, 1995; Komárek and Anagnostidis, 1999, 2005).

The cultures of phototrophic microorganisms were analysed using molecular biology techniques for the identification of cyanobacteria and eukaryotes. DNA was extracted using FastDNA SPIN for Soil Kit (MP Biomedicals, Santa Ana, CA, USA) in conjunction with the FastPrep instrument, following the manufacturer's protocol. Amplifications of $16 \mathrm{~S}$ and $18 \mathrm{~S}$ rRNA gene sequences were performed by PCR using the cyanobacteria-specific primer pair, Cya106F and Cya781R (Nübel et al., 1997), and the Eukarya-specific primers, EukA and EukB (White et al. 1990), respectively. 
PCR amplifications were performed using the following thermal conditions: $95^{\circ} \mathrm{C}$

\section{Results}

\subsection{Material properties}

The calcarenite host rock consisted of $75-85 \%$ calcareous grains (lamellibranchia predominating over oysters and small foraminifera). The remaining $15-25 \%$ was mainly quartz and trace amounts of phyllosilicates (smectite and illite). A matrix was rarely present in the calcarenite, and when present it consisted of very fine calcareous clay and lime-size grains. Calcite cement, with equant and drusy textures, was also rare and it was concentrated at the grain contacts.

The calcarenite showed a complex porous media, with high porosity $(24-33 \%)$ and polymodal pore size distribution. These pore space properties provided an important water condensation, capillary rise and salt weathering susceptibility. Moreover, calcarenite showed a very low mechanical strength, as revealed by axial compressive strength $(5.90 \mathrm{MPa})$. A detailed description of the host rock physical properties can be found in Benavente et al. (2011), who studied the Postumius Tomb located in the same lithologic unit of Circular Mausoleum.

The composition of the stuccos was calcite $(70 \%)$, quartz (13\%) and feldspar (17\%); for fine-grained mortars the composition was calcite (77\%) and quartz (23\%); and for coarse-grained mortars calcite (46\%), quartz (23\%), gypsum (19\%) and feldspar (12\%) were identified. Calcite was found as aggregate and blinder in the studied stuccos and mortars.

Stuccos and fine and coarse-grained mortars presented similar specific surface area (SSA) values $\left(48.6,41.2\right.$ and $53.7 \mathrm{~m}^{2} / \mathrm{g}$, respectively), whereas the host rock showed the smallest SSA values $\left(2.7 \mathrm{~m}^{2} / \mathrm{g}\right)$. Scanning electron microscopy observations showed an important volume fraction (porosity) in the studied materials, although the host rock presented largest pores than stuccos and mortars. Materials with high porosity but small mean pore size (for example, stuccos and mortars) presented higher SSA values than materials with a large mean pore radius (host rock). 


\subsection{Microclimatic characterization}

The microclimate of the Circular Mausoleum and outdoor environmental parameters during the monitoring period are shown in Figure 3. In the hydrological cycle between September 2007 and August 2008, the exterior average temperature was $18.7^{\circ} \mathrm{C}$, with monthly temperature variations ranging between $15.3^{\circ} \mathrm{C}$ (December) and $27.4^{\circ} \mathrm{C}$ (June). Annual average relative humidity was around $61 \%$ with a high level of short-term (daily) and seasonal fluctuations. The area was characterized by low annual rainfall $\left(383.4 \mathrm{~L} / \mathrm{m}^{2}\right)$ with long periods of drought (June-August). The maximum rainfall was in spring $\left(114.2 \mathrm{~L} / \mathrm{m}^{2}\right.$ in April 2008) and autumn (71.4 L/ $\mathrm{m}^{2}$ in November 2007).

The average air temperature inside the Circular Mausoleum during the same hydrological cycle (2007-2008) was $17.73^{\circ} \mathrm{C}$ with moderate values of both diurnal $\left(5.62^{\circ} \mathrm{C}\right)$ and annual variation $\left(18.54^{\circ} \mathrm{C}\right)$. The temperature evolution inside the tomb was parallel to the outer atmosphere but with temperature values significantly higher than those registered outside during winter (Fig. 3). A thermal equilibrium between the tomb's air and the surface of the inner walls and ceiling tended to be reached during winter months. This equilibrium suddenly changed in early spring when the rock temperature kept warmer than the air until early autumn. The evolution of the rock temperature at the two control points indicated a significant overheating of the ceiling (T2, annual average of $18.82^{\circ} \mathrm{C}$ with an annual oscillation of $17.28^{\circ} \mathrm{C}$ ) compared to the walls (T1, annual average of $18.04^{\circ} \mathrm{C}$ with an annual oscillation of $16.68^{\circ} \mathrm{C}$ ).

The relative humidity of the indoor air was moderately high, with an annual average value of $78.5 \%$ for the hydrological year 2007-2008. Its evolution was parallel to the exterior atmosphere (Fig. 3), with similar values during autumn and early winter (November to January). The greatest similarity of humidity conditions between inner and exterior air was related to ventilation favoured by the entry of cold, dense air from the outside during the coldest months. However, since February the internal humidity values were consistently above the external humidity (except for intervals with sharp external thermal dropping that caused new transient ventilation processes). The relative humidity differences between the inner and outer atmosphere were accentuated during the summer.

\subsection{Condensation processes on the inner surfaces of the tomb}

A detailed time-evolution of vapour condensation on the inner surfaces (e.g. rocksurface of ceiling) can be calculated in function of the microclimate conditions and pore structure properties of rock.

Figure 3 shows the amount of water condensing on the rock surface of ceiling per cubic meter of air within the tomb, during the monitoring period. Effective 
condensation occurred when the relative humidity of the tomb air reached and

\subsection{Models of duration of insolation, light flux and surface temperature}

In general, direct potential insolation in the area occupied by the Roman Necropolis of Carmona was quite high and the overall climate conditions were warm the year round. In the area surrounding the studied tomb, the maximum direct potential insolation during the winter solstice reached $1842 \mathrm{~W} / \mathrm{m}^{2}$ with average values of $1027 \mathrm{~W} / \mathrm{m}^{2}$. In the equinoxes this increased up to $4240 \mathrm{~W} / \mathrm{m}^{2}$ with average values of $3475 \mathrm{~W} / \mathrm{m}^{2}$. During the summer solstice the maximum value reached $6039 \mathrm{~W} / \mathrm{m}^{2}$ with an average of $5792 \mathrm{~W} / \mathrm{m}^{2}$ (Fig. 4B). In the area were the tomb is located, which is flat and not protected from solar radiation, an important increase of the direct potential insolation from winter to summer was observed. This increase was more prominent from the spring equinox to the summer solstice than from the winter solstice to the spring equinox.

The duration of insolation models (Fig. 4A) showed that over a year changes in duration and location of direct insolation from the entrance to the interior of the tomb were very noticeable. During the winter solstice and the equinoxes, there was no direct insolation in the interior of the tomb and it was very limited in the uppermost area of the tomb entrance. In turn, during the summer solstice, the insolation reached a great area of the tomb interior through the shaft, from 1 to 3 hours. On the roof of the tomb $(40 \mathrm{~cm}$ thick), exposed the year round to direct insolation, an expected increase of insolation from 9 to 10 hours during winter solstice and equinoxes to more than 15 hours during the summer solstice was reported. The models of insolation for each season were consistent with the continuous records of light intensity performed inside the tomb, in particular with those registered on the east wall. From November to March light was undetectable 
(Fig. 4C); from middle March low levels of solar radiation started to be registered, increasing gradually till reaching their highest values in June-July.

The luminous flux for each sampling campaign displayed minor variations in both range of values and spatial distribution inside the tomb, which were related to its shape. In general, the luminous flux distribution inside the tomb depended on the season and time of the day, i.e. it was dependent on the relative position and inclination of the sun relative to the orientation of the tomb entrance. Incident light from the sun was reflected on the ground and walls of the entrance and on the roof of the tomb. Seasonal changes were noticeable and luminous flux increased from winter to summer mainly in the external zones of the tomb (Fig. $4 A, B)$.

Surface temperature in the internal areas of the Circular Mausoleum was closely related to the outside air temperature. For all sampling campaigns, the minimum and maximum surface temperature values were 9.5 and $26.0^{\circ} \mathrm{C}$, respectively, and the average values ranged from 11.6 to $23.04^{\circ} \mathrm{C}$. The surface temperature variations in each campaign ranged from 3.5 to $7.1^{\circ} \mathrm{C}$. In all data collection campaigns, temperature increases upward and inward from the tomb, the increasing ranging from 0.1 to $3^{\circ} \mathrm{C}$. Daily evolution near the summer solstice clearly showed a broad area of steady temperatures and an increase towards the outside of the tomb (with an important cooling in the ceiling and walls). On the contrary, daily evolution in October (equinox) showed a cooling of a great part of the Circular Mausoleum, with higher stability in the most internal part of the tomb.

\subsection{Weathering and biodeterioration}

The Circular Mausoleum shows a severe alteration and different types of weathering forms can be distinguished. Visual examination of weathering forms comprising deposits and loss of material were abundant. In general, the most important weathering forms included loss and deformation of material (granular or crumbly disintegration, scaling, flaking, blistering, etc.) and surface modifications (efflorescence, encrustations and biological colonization) (Fig. 5).

The tomb walls displayed complex weathering patterns, represented by granular disintegration, crumbling or scaling. In some places (ceiling and niches) the surface recession was very significant (Fig. 5A), reaching several $\mathrm{cm}$ deep. In the ceiling, original mortars and stuccos were not preserved.

Deformation features, as bumps or blisters on the areas with stuccos, especially in the entrance area were relatively abundant. These were commonly associated with anthropogenic actions including graffiti scratches (Fig. 5D). Biological colonization was also influenced by vandalism episodes as observed in Figure $5 \mathrm{E}$.

Diverse types of deposits have been recognized: (i) Crumbly fine-grained deposits on the surface of niche ledges (soiling), mainly composed of phototrophic 
microorganisms and insect remains; (ii) salt efflorescence on walls, niches, rock, coatings and encrustations.

Efflorescence was mostly composed of gypsum and covered all types of substrates. Sodium sulfate salts were scarce. Efflorescence usually showed a powdery or finegrained texture when directly covered the rock substrate (calcarenite) or coarsegrained mortar. On the surface of stuccos was also common the existence of a discontinuous deposit of gypsum crystals derived from the dissolution and recrystallization of gypsum efflorescences, giving a characteristic 'mikado'-like texture (Fig. 5C). Microcrystalline gypsum deposits also appeared as subefflorescences, usually under stucco or mortar layers. These deterioration patterns were solely visible at a mesoscale when the upper mortar or stucco layers were detached. Encrustations firmly adhered to the stone surface were generally observed. They showed different typologies from globulitic to thin smooth cryptocrystalline encrustations. Globulitic crusts formed smooth and rough surfaces on both mortars and stuccos and on calcarenitic substrate (Fig. 5B,C). Thin smooth cryptocrystalline encrustations were found covering mortars, and often drawing thread-like trails or paths (Fig. $5 F, G$ ). All of these phenomena were clearly due to precipitation processes, but formation mechanisms could be diverse. Globulitic botryoidal types were associated with seepage of infiltration water and/or condensation processes, whereas smooth cryptocrystalline encrustations were associated with flowing water (Fig. 5F, G).

Biological colonization was widespread inside the tomb. Microbial colonies distribution was highly controlled by the entrance orientation (facing west) and the distance to the ground. Photosynthetic-based colonization was particularly extended in holes and rough substrates (Fig. $5 \mathrm{H}$ ). In the entrance (shaft) the walls were colonized by lichens (Fig. 5I), mosses, and phototrophic microorganisms.

Figures 6 and 7 show alteration maps, illustrating the spatial distribution of the major weathering forms developed on the inner arch and on the end (eastern) wall of the tomb.

On the wall of the inner arch (Fig. 6), the spatial distribution of the weathering forms exhibited a vertical zonation. Encrustations were much more widespread at the bottom than at the intermediate and upper zones, with efflorescence on the ceiling. Biologically induced deposits preferentially accumulated at the bottom. This zonation was not evident on the eastern wall (Fig. 7), where the nature of the substrate (composition and roughness), water condensation and laminar flow processes on the wall largely controlled the distribution of the weathering forms. On this wall, different phases of restoration involving mortars application were observed (Fig. 8). Some mortars were clear toned, coarse-textured, and well differentiated between them by the degree of alteration (blisters, efflorescence, and scabs). Recent mortars with brown coloration and finer grained texture also showed alteration, especially on the edges (deformations, efflorescence, etc.). 


\subsection{Phototrophic colonization}

Figure 9 and Table 1 summarizes the characteristics of the samples analysed in the Circular Mausoleum tomb, where phototrophic microorganisms reached a particular relevance. While the shaft of access to the tomb had direct insolation and the walls were mainly coated by the lichen Dirina massiliensis (Fig. 5l), the arch and the interior of the tomb were populated by cyanobacteria and algae. The walls near the ground level were characterized by the predominance of chlorophyta over cyanobacteria (L12, MC1 and 2), while cyanobacteria were mostly present on or near the ceiling (MC3, MC4 and MC5). Direct microscopic observations of the samples identified among the chlorophyta Muriella terrestris and Muriella sp., while the cyanobacteria were represented by Cyanothamnos sp., Chroococcidiopsis sp., Symplocastrum friesii, Leptolyngbya spp., Gloeocapsa rupestris, and Scytonema sp. When the samples were cultured in the laboratory, the dominant species in the plates were the chlorophyta Chlorella vulgaris and Ctenocladus circinnatus, and the cyanobacteria Symplocastrum friesii, Leptolyngbya spp., Chroococcidiopsis sp. and Gloeocapsa rupestris. Additional molecular studies revealed that Loriellopsis cavernicola was present in sample L12, Jenufa minuta in samples MC1 and MC2, and Leptolyngbya sp. and Oculatella sp. in sample MC4.

\section{Discussion}

The Circular Mausoleum showed a high degree of deterioration. The nature of the building materials and the numerous interventions works in the tomb increased damages promoted by high humidity and condensation rates. In fact, mineralogical, textural and petrophysical characterization of the host rock pointed out to a high susceptibility to decay for this calcarenite, which corroborated the similar nature of host rocks of the Circular Mausoleum and the previously studied Postumius Tomb, both in the same sedimentary sequence (Benavente et al., 2011). Deterioration patterns were observed in the calcarenite host rock and stuccos/mortars substrates. They comprised a varied and abundant array of damages, including material detachment (scaling, flaking, granular disintegration), surface discoloration, deposits (efflorescence and crusts), and biological colonization (Figs. 6 and 7).

The deterioration processes observed in the tomb can be summarized as:

- Dissolution/crystallization of salts on the porous system (host rock, stuccos and mortars) due to: (i) the presence of liquid water (flooding or condensation) and capillary absorption kinetics, and (ii) daily and seasonal relative humidity variations in the tomb.

- Dissolution of calcarenite substrate, which caused loss of cohesion and subsequent granular or crumbly disintegration. Both water (liquid or vapour) 
and $\mathrm{CO}_{2}$ (air, natural and anthropogenic soil covering the rock) were the main factors in the dissolution of the carbonate rock.

- Anthropogenic actions involving archaeological excavations and vandalism (engraving and scratching) resulting in important mechanical damages on the surface and loss of substrate material.

- Biofilm development and subsequent biodeterioration. An important biological activity by phototrophic microorganisms was promoted due to high humidity, natural dim light and mineral availability.

The combined action of these alteration processes gave rise to the current severe deterioration state of the Circular Mausoleum, in which water was the principal agent of deterioration.

The seasonal and daily cycles of heating-cooling and the important direct solar radiation over the tomb roof causing overheating, implied the decreasing of air relative humidity and increasing of building material temperatures. These cycles not only enhanced weakness of the joint host rock-mortar by differential thermal stress but also disintegration of the mortars, stuccos and rock, and crystallizationdissolution of salts. Wetting-drying cycles, responsible of salt precipitation, were particularly evident at the rock-mortar interface due to different pore size distributions.

Pore structure characterization showed that these materials presented a significant porosity. SSA revealed that stuccos and mortars had thin pores whereas the host rock showed large mean pore radius. SSA is directly related to porosity and inversely related to pore size (Benavente et al., 2007; Benavente, 2011) and therefore, provides pore structure information related to decay mechanisms. Thus, high SSA values imply a high susceptibility to salt weathering (Benavente et al., 2007), capillary stress (Benavante et al., 2008), high capacity to water condensation and retention within porous materials, and consequently, high bioreceptivity (Sanchez-Moral et al., 2005; Miller et al. 2012). In addition, the presence of a water film might decrease the free surface energy of the material, decreasing its strength. The material aptitude to water retention had also an impact on the calcite dissolution, promoting material detachment (granular disintegration, scaling, etc.).

The high relative humidity and the petrophysical properties of the substrates promoted water condensation inside the tomb, especially in winter (Benavente et al., 2011; Fernandez-Cortes et al., 2013). The procedure to calculate the amount of water condensing on an exposed rock/soil surface was extensively described by Fernandez-Cortes et al. (2013). It depends on: 1) the evolution over time of the differences in vapour pressure between air and the rock/soil surface, and 2) the control exerted by the rock porous system based on laboratory experiments to calculate water adsorption curves of rock/soil samples at different relative humidity. The effective condensation occurs when vapour pressure in the air is 
higher than on the rock surface, which is corrected by a threshold of relative pore structure and dissolved salts. It has been previously tested on laboratory for several host rock samples from the same lithostratigraphic unit where the tomb was carved, revealing a relative humidity threshold for the tomb air of $70-75 \%$, from which the amount of water adsorbed by the porous surface system significantly increased (Benavente et al., 2011).

In summer, the lack of air ventilation due to the narrow vertical entrance (shaft) of the tomb resulted in the entrapment of cold and wet air from the outside, causing a moisture gradient between the inner floor and ceiling which activated water capillary rise through tomb walls and promotes biological colonization.

The colonization of rocks by phototrophic communities in subterranean environments is often associated with sites of high humidity and low light intensity, as occurring in the Circular Mausoleum. However the combination of other different ecological factors, such a temperature and nutrient availability may also influence the distribution of such microorganisms due to specific adaptations to the conditions prevailing in a niche (Figs. 6 and 7). Most of the phototrophic microorganisms found are ubiquitous in subterranean environments, but a considerable number of species are endemic forms or even new species that in the last few years where described for the first time (Lamprinou et al. 2011).

Colonization of subterranean environments by phototrophic microorganisms depends on light, water and nutrient availability. In this tomb several sources or nutrients are available for microbial growth and biofilms: i) organic carbon and soluble salts carried out by rainwater and flooding of the tomb in raining seasons, ii) soluble salts and dissolved organic carbon brought by ascending capillarity in warm seasons, iii) activity of insects and small animals (spiders, geckos, etc.), which contributes to the dispersion of microorganisms all around the tomb walls and ceiling. Although this study was focused on phototrophic microorganisms, heterotrophic microorganisms such as bacteria and fungi also form part of the biofilms (Lappin-Scott and Costerton, 1995).

In the past some small tombs from this Necropolis were investigated and a calcifying cyanobacterial community represented by Scytonema julianum and Geitleria calcarea was identified (Ariño et al. 1997). In some other tombs the studies were focused on the lichenic community (Ariño and Saiz-Jimenez, 1997).

In the Circular Mausoleum, calcifying cyanobacteria were rarely observed and only Scytonema sp. was identified by direct microscopic observation (Table 1). In this tomb, spatial variations in light intensity and humidity may even led to species segregation in adjacent materials. In fact, the particular microclimate conditions in this tomb gave rise to special niches for phototrophic microorganisms. Chlorophyta were common near the ground level due to the high moisture content the year round. In contrast, cyanobacteria were especially successful on the ceiling and 
adjacent walls, where abundant cracks and holes were present with very low light ceiling, reaching high temperatures due to insolation, the presence of cyanobacteria was remarkable which indicates a better adaptation to dryness. Therefore, there is a clear trend in the ecology of phototrophic microorganisms in this tomb.

The resistance of cyanobacteria to extreme environmental conditions has been reported by several authors (Ortega-Calvo et al, 1992; Ariño and Saiz-Jimenez, 1996). Particularly, the genus Chroococcidiopsis is characterized by the ability to survive prolonged desiccation periods, dominating the most extreme arid habitats (Billi et al., 2000). Therefore it is not surprising the finding of Chroococcidiopsis on the ceiling of this tomb and on the upper parts of the walls subjected to high insolation in summer. Some other cyanobacteria, such as Gloeocapsa rupestris, Symplocastrum friesii, Leptolyngbya sp. and Oculatella sp., have thick mucilaginous sheath and cells are encased in a protective extracellular matrix composed predominantly of polysaccharides. This matrix protects the cells from desiccation (Büdel et al. 2009; Albertano, 2012).

It should be noticed that in Table 1 some differences were observed between the phototrophic microorganisms directly identified from the fresh sample and those identified after culturing. These differences were due to the fact that some cyanobacteria and algae were more prone to grow in culture media than others and in this way the most abundant species identified in cultures could not be necessarily those present in fresh samples collected from the tomb.

For taxonomical identification of cyanobacteria, the establishment of genera is based on both the molecular evaluation of genotypes and phenotypic characters, which are continually corrected and updated (Hoffmann et al., 2005; Komárek et al., 2014). Different hypogean-adapted species with morphological similarity could be attributed to highly convergent forms that can mask taxonomic relationships and morphologically similar types are indistinguishable or barely distinguishable. Some species found in the Circular Mausoleum represent an example of shared morphology in genetically different strains such as the genera Chlorella and Jenufa. In fact, we observed Muriella terrestris in the samples collected while after a few weeks of culture the Petri dish was dominated by Chlorella vulgaris. In 2011 the genus Jenufa was separated from Chlorella based on molecular evidences, although morphologically both genera were similar and even similar to some Muriella (Nemcová et al., 2011).

Loriellopsis cavernicola and Iphinoe spelaeobios represent an example of shared morphology in genetically different strains, as well. Both are components of natural populations in subterranean environments with a disjointed and worldwide distribution (Lamprinou et al. 2011), where dim light seems to be a major stress factor. Loriellopsis cavernicola was found in a previous sampling in the Circular Mausoleum and in Servilia tomb, at some $100 \mathrm{~m}$ from the former. Iphinoe 
spelaeobios was further identified in this tomb associated with some

\section{Conclusions and recommendations}

This study showed that the Circular Mausoleum has suffered from a severe deterioration since its discovery and exhumation. The nature of the host rock, a soft calcarenite, and the intervention works over time enhanced the observed damage.

Since its construction, the tomb has passed through several stages in which alteration processes were varied in types and degree of intensity (Fig. 10). After the discovery of the Circular Mausoleum, intervention works caused changes in the tomb access and in the interior, which represented a radical modification in their environmental conditions (Fig. 10A-C). The chamber opening through the eastern side and excavation and partial destruction of the superstructure (dome) expedited the libation conduit (Fig. 10C). A subsequent intervention resulted in the opening 
of the original entrance to the chamber and the closure of the former entrance

\section{Acknowledgements}

This research was funded by the Consejeria de Cultura, Junta de Andalucia, the Spanish Ministry of Science and Innovation project CGL2010-17183, and the program Torres Quevedo (PTQ 13-06296 and PTQ 12-05601). We thank the staff of Archaeological Site of Carmona for their collaboration.

\section{References}

Albertano, P., 2012. Cyanobacterial biofilms in monuments and caves. In: Whitton, B.A. (ed.), Ecology of Cyanobacteria II: Their Diversity in Space and Time, Dordrecht: Springer, pp. 317-343.

Altschul, S.F., Gish, W., Miller, W., Myers, E.W., Lipman, D.J., 1990. Basic local alignment search tool. J. Mol. Biol. 215, 403-410.

Ariño, X., Saiz-Jimenez, C., 1996. Factors affecting the colonization and distribution of cyanobacteria, algae and lichens in ancient mortars. In: Riederer, J. (ed.), 8th International Congress on Deterioration and Conservation of Stone, vol. 2, pp. 725-731. 
Ariño, X., Saiz-Jimenez, C., 1997. Deterioration of the Elephant tomb (Necropolis of Carmona, Seville, Spain). Int. Biodeter. Biodegr. 40, 233-239.

Ariño, X., Hernandez-Marine, M., Saiz-Jimenez, C., 1997. Colonization of Roman tombs by calcifying cyanobacteria. Phycologia 36, 366-373.

Benavente D., 2011. Why pore size is important in the deterioration of porous stones used in the built heritage? Macla 15, 41-42.

Benavente D., Cueto N., Martínez-Martínez J., García-del-Cura M.A., Cañaveras J.C., 2007. Influence of petrophysical properties on the salt weathering of porous building rocks. Environ. Geol. 52, 197-206.

Benavente D., Cultrone G., Gómez-Heras M., 2008. The combined influence of mineralogy, hydric and thermal properties in the durability of porous building stones. Eur. J. Mineral. 20, 673-685.

Benavente, D., Sanchez-Moral, S., Fernandez-Cortes, A., Cañaveras, J.C., Elez, J., Saiz-Jimenez, C., 2011. Salt damage and microclimate in the Postumius Tomb, Roman Necropolis of Carmona, Spain. Environ. Earth Sci. 63, 1529-1543.

Bendala, G., 1976. La necrópolis romana de Carmona (Sevilla). Diputacion de Sevilla, 140 p.

Billi, D., Imre Friedmann, E., Hofer, K.G., Grilli Caiola, M., Ocampo-Friedmann, R., 2000. lonizing-radiation resistance in the desiccation-tolerant cyanobacterium Chroococcidiopsis. Appl. Environ. Microbiol. 66, 1489-1492.

Bourrelly, P., 1990. Les algues d'eau douce - Initiation à la systématique, I: Les Algues Vertes. N. Boubée, Paris, 572 p.

Büdel, B., Darienko, T., Deutschewitz, K., Dojani, S., Friedl, T., Mohr, K.I., Salisch, M., Reisser, W., Weber, B., 2009. Southern African biological soil crusts are ubiquitous and highly diverse in drylands, being restricted by rainfall frequency. Microb. Ecol. 57, 229-247.

Dubayah, R., Rich, P.M., 1995. Topographic solar radiation models for GIS. Int. J. Geogr. Inf. Syst. 9, 405-413.

Dubayah, R., Rich, P.M., 1996. GIS-based solar radiation modeling. In: Goodchild, M.F., Steyaert, L.T., Parks. B.O., Johnston, C., Maidment, D., Crane, M., Glendinning, S. (eds.). GIS and Environmental Modelling: Progress and Research Issues. Fort Collins: GIS World Books, pp. 129-134.

Ettl, H., Gärtner, G., 1995. Syllabus der Boden, Luft und Flechtenalgen. Stuttgart: G. Fischer, $721 \mathrm{p}$.

Fernandez-Cortes, A., Benavente, D., Cuezva, S., Cañaveras, J.C., Alvarez-Gallego, M., Garcia-Anton, E., Soler, V., Sanchez-Moral, S., 2013. Effect of water vapour condensation on the radon content in subsurface air in a hypogeal inactivevolcanic environment in Galdar cave, Spain. Atmos. Environ. 75, 15-23. 
Fu, P., Rich, P.M., 1999. Design and implementation of the Solar Analyst: An ArcView extension for modeling solar radiation at landscape scales. In: Proceedings of the 19th Annual ESRI User Conference. San Diego, CA: ESRI. Retrieved July 9, 2008, from http://gis.esri.com/library/userconf/ proc99/proceed/papers/pap867/p867.htm

Fu, P., Rich, P.M., 2000. The Solar Analyst 1.0 User Manual. Lawrence: Helios Environmental Modeling Institute, $49 \mathrm{p}$.

Heinrichs, K., Fitzner, B., 2000. Deterioration of rock monuments in Petra/Jordan. In: Fassina, V. (ed.), Proceedings of the 9th International Congress of the Deterioration and Conservation of Stone, vol. 2, Amsterdam: Elsevier, pp. 5361.

Hoffmann, L., Komárek, J., Kastovsky, J., 2005. System of cyanoprokaryotes (cyanobacteria)-state in 2004. Algol. Stud. 117, 95-115.

Huber, T., Faulkner, G., Hugenholtz, P., 2004. Bellerophon: a program to detect chimeric sequences in multiple sequence alignments. Bioinformatics 20, 23172319.

ICOMOS-ICS, 2008. Illustrated glossary on stone deterioration pattern. http://international.icomos.org/publications/monuments_and_sites/15/pdf/Mo numents_and_Sites_15_ISCS_Glossary_Stone.pdf).

Komárek, J., Anagnostidis, K., 1999. Cyanoprokaryota 1. Chroococcales. In: Ettl, H., Gärtner, G., Heynig, H., Mollenhauer, D. (eds.), Süßwasserflora von Mitteleuropa, 19/1, Heidelberg: Spektrum, 548 p.

Komárek, J., Anagnostidis, K., 2005. Cyanoprokaryota 2. Oscillatoriales. In: Büdel, B., Krienitz, L., Gärtner, G., Schagerl, M. (eds.) Süsswasserflora von Mitteleuropa 19/2. Heidelberg: Elsevier, 759 p.

Komárek J., Kaštovský J., Mareš J., Johansen J.R., 2014. Taxonomic classification of cyanoprokaryotes (cyanobacterial genera) 2014, using a polyphasic approach. Preslia 86, 295-335.

Laiz, L., Miller, A.Z., Jurado, V., Akatova, E., Sanchez-Moral, S., Gonzalez, J.M., Dionisio, A., Macedo, M.F., Saiz-Jimenez, C., 2009. Isolation of Rubrobacter strains from biodeteriorated monuments. Naturwissenschaften 96, 71-79.

Lamprinou, V., Hernández-Mariné, M., Canals, T., Kormas, K., Economou-Amilli, A., Pantazidou, A., 2011. Morphology and molecular evaluation of Iphinoe spelaeobios gen. nov., sp. nov. and Loriellopsis cavernicola gen. nov., sp. nov., two stigonematalean cyanobacteria from Greek and Spanish caves. Int. J. Syst. Evol. Microbiol. 61, 2907-2915.

Lappin-Scott, H.M., Costerton, J.W., 1995. Microbial biofilms. Cambridge: University Press, $315 \mathrm{p}$. 
Maier Allende, J., 1999. Jorge Bonsor (1885-1930). Un académico correspondiente de la Real Academia de la Historia y de la Arqueología Española. Madrid: Real Academia de la Historia, $300 \mathrm{p}$.

Miller, A.Z., Sanmartin, P., Pereira-Pardo, L., Dionisio, A., Saiz-Jimenez, C., Macedo, M.F., Prieto B., 2012. Bioreceptivity of building stones. A review. Sci. Total Environ. 426, 1-12.

Nemcová, Y., Eliás, M., Skaloud, P., Hodac, L., Neustupa, J., 2011. Jenufa gen. nov.: A genus of coccoid green algae (Chlorophyceae, incertae sedis) previously recorded by environmental sequencing. J. Phycol. 47, 928-938.

Nübel, U., Garcia-Pichel, F., Muyzer, G., 1997. PCR primers to amplify $16 \mathrm{~S}$ rRNA genes from cyanobacteria. Appl. Environ. Microbiol. 63, 3327-3332.

Ortega-Calvo, J.J., Hernández-Marine, M., Saiz-Jimenez, C., 1992. Experimental strategies for investigation stone algal colonization. In: J. Delgado Rodrigues, F. Henriques and F. Telmo Jeremias (eds.), 7th International Congress on Deterioration and Conservation of Stone. Lisboa: Laboratorio Nacional de Engenharia Civil, pp. 541-549.

Piñar, G., Saiz-Jimenez, C., Shabereiter-Gurtner, C., Blanco-Varela, M.T., Lubitz, W., Rölleke, S., 2001. Archaeal communities in two disparate deteriorated ancient wall paintings: detection, identification and temporal monitoring by DGGE. FEMS Microbiol. Ecol. 37, 45-54.

Rada y Delgado, J.D., 1885. Necrópolis de Carmona: Memoria escrita en virtud de acuerdo de las Reales Academias de la Historia y de Bellas Artes de San Fernando. Madrid: Real Academia de la Historia, 179 p.

Roldán M., Hernández-Mariné M., 2009. Exploring the secrets of the threedimensional architecture of phototrophic biofilms in caves. Int. J. Speleol. 38, 41-53.

Sanchez-Moral, S., Luque, L., Cuezva, S., Soler, V., Benavente, D., Laiz, L., Gonzalez, J.M., Saiz-Jimenez, C., 2005. Deterioration of building materials in Roman catacombs: the influence of visitors. Sci. Total. Environ. 349, 260-276.

White, T.J., Bruns, T., Lee, S., Taylor, J., 1990. Amplification and direct sequencing of fungal ribosomal RNA genes for phylogenetics. In: Innis, M.A., Gelfand, D.H., Sninsky, J.J., White, T.J. (eds.), PCR protocols: A guide to Methods and Applications. New York: Academic Press, pp. 315-322.

Zammit, G., Billi, D., Albertano, P., 2012. The subaerophytic cyanobacterium Oculatella subterranea (Oscillatoriales, Cyanophyceae) gen. et sp. nov.: a cytomorphological and molecular description. Eur. J. Phycol. 47, 341-354. 


\section{FIGURE CAPTIONS}

Figure 1. A. Location of Circular Mausoleum (CM) in the Carmona Necropolis Archaeological Site. B. The Circular Mausoleum in the lithostratigraphic profile. C. 3D-scheme of the Circular Mausoleum.

Figure 2. Variation in light intensity measured in the morning of January 28, 2009.

Figure 3. Temporal evolution of the external climatic conditions and main microclimatic parameters inside the tomb (temperature and relative humidity of air, rock-surface temperature and effective condensation process in the rock surface of the ceiling.

Figure 4. A. Evolution of the modelled duration of the insolation at the entrance of the tomb (3D simplified model) during an annual cycle. B. Summer solstice model of the direct insolation. C. Evolution of the light intensity recorded at the Tomb of Circular Mausoleum during the annual cycle April 2008 - April 2009.

Figure 5. A. Gravitational crusts near to niche edges probably associated with the drain of condensation water. B. Globulitic encrustation. C. Detail of globulitic precipitates and associated microorganisms (cyanobacteria and algae). D. Flakes and blisters associated with anthropogenic scratches. E. Details of how a scratch can transport spores and induce a microbial colonization characterized by a violet diffusible pigment. F. Green biofilms in trails related to gravitational encrustations. Colonies must be associated to water condensation and subsequent runoff processes. G. Details of vertically-arranged green biofilms in association to gravitational encrustations. Like the latter, the settlements should be associated with processes of condensation and water runoff. $\mathrm{H}$. Phototrophic biofilms on rough substrate (due to spalling, disaggregation). I. Lichens (Dirina massiliensis) in the entrance of the tomb (shaft).

Figure 6. Distribution of weathering forms on the inner arch wall of the Circular Mausoleum.

Figure 7. Distribution of weathering form on the eastern wall of the Circular Mausoleum.

Figure 8. Different types of restoration materials on the inner wall of the Circular Mausoleum. A. Rough, gray-colored, highly altered substrate (blisters, efflorescences, botryoidal crusts, etc.). A'. Rough, gray-colored, slightly altered substrate. B. Brown-colored substrate with edges alterations (efflorescences and flakes).

Figure 9. Phototrophic colonization in the Circular Mausoleum. A. Green biofilm on the eastern wall of the tomb, near the ground. B. Thin green biofilm on the eastern wall. C. Thin green biofilm on the left side of the inner arch. D) Green biofilm on the tomb ceiling. E. Green biofilm at the entrance. F. Green biofilm on the northern wall, near the tomb ceiling. 
Figure 10. Evolution stages of the Circular Mausoleum. A. Roman phase. The tomb was in use. B. Burial phase. The tomb was abandoned. Between the abandoned state and its discovery, the tomb was buried preventing flooding phenomena and air circulation. C. Discovery phase (last decades of 19th century). It comprised opening of the tomb through the eastern wall and destruction of structural elements. D. Present stage. Restoration of the dome structure (roof). Liquid water (flooding or condensation) and capillary movement during raining periods are frequent. High RH, temperature gradient, and condensation in the tomb are experienced during summer. E. Proposed corrective phase. 
Click here to download Table: Table 1.docx

Table 1. Phototrophic colonization in the Circular Mausoleum

\begin{tabular}{|c|c|c|c|c|}
\hline Sample & Sample description & $\begin{array}{l}\text { Phototrophic microorganisms } \\
\text { identified on fresh samples }\end{array}$ & $\begin{array}{l}\text { Dominant phototrophic } \\
\text { microorganisms identified } \\
\text { after culturing }\end{array}$ & $\begin{array}{l}\text { Molecular identification of } \\
\text { cultures, accession } \\
\text { number and \% similarity }\end{array}$ \\
\hline $\mathrm{L} 12$ & $\begin{array}{l}\text { Green biofilm developing on the } \\
\text { rough substrate from the } \\
\text { easternwall of the tomb, near } \\
\text { the ground (Fig. } 9 \mathrm{~A} \text { ). }\end{array}$ & $\begin{array}{l}\text { Muriella sp. } \\
\text { Cyanothamnos sp. } \\
\text { Chroococcidiopsis sp. }\end{array}$ & $\begin{array}{l}\text { Chlorella vulgaris } \\
\text { Symplocastrum friesii }\end{array}$ & $\begin{array}{l}\text { Loriellopsis cavernicola } \\
\text { NR117881 }(91 \%)\end{array}$ \\
\hline MC1 & $\begin{array}{l}\text { Thin green biofilm developing on } \\
\text { the flat substrate from the } \\
\text { eastern wall, near the ground } \\
\text { (Fig. 9B). }\end{array}$ & Muriella terrestris & Chlorella vulgaris & $\begin{array}{l}\text { Jenufa minuta HM563744 } \\
(99 \%)\end{array}$ \\
\hline$M C 2$ & $\begin{array}{l}\text { Thin green biofilm developing on } \\
\text { the flat substrate from the left } \\
\text { side of the inner arc (Fig. } 9 C \text { ). }\end{array}$ & $\begin{array}{l}\text { Muriella terrestris } \\
\text { Symplocastrum friesii }\end{array}$ & $\begin{array}{l}\text { Chlorella vulgaris } \\
\text { Ctenocladus circinnatus }\end{array}$ & $\begin{array}{l}\text { Jenufa minuta } \mathrm{HM} 563744 \\
(99 \%)\end{array}$ \\
\hline $\mathrm{MC} 3$ & $\begin{array}{l}\text { Green biofilm developing on the } \\
\text { rough substrate from the ceiling } \\
\text { of the tomb (Fig. 9D). }\end{array}$ & $\begin{array}{l}\text { Chroococcidiopsis sp. } \\
\text { Gloeocapsa sp. }\end{array}$ & Gloeocapsa rupestris & N.D \\
\hline$M C 4$ & $\begin{array}{l}\text { Green biofilm developing on the } \\
\text { rough substrate of the left } \\
\text { corridor wall of the tomb (Fig. } \\
9 \mathrm{E} \text { ). }\end{array}$ & $\begin{array}{l}\text { Chroococcidiopsis sp. } \\
\text { Gloeocapsa rupestris } \\
\text { Symplocastrum friesii } \\
\text { Scytonema sp. }\end{array}$ & $\begin{array}{l}\text { Chroococcidiopsis sp. } \\
\text { Gloeocapsa rupestris } \\
\text { Symplocastrum friesii }\end{array}$ & $\begin{array}{l}\text { Leptolyngbya sp. } \\
\text { HM217061 (99\%) } \\
\text { Oculatella sp. KC } 311928 \\
(99 \%)\end{array}$ \\
\hline$M C 5$ & $\begin{array}{l}\text { Green biofilm developing on the } \\
\text { rough substrate from the } \\
\text { northern wall, near the ceiling } \\
\text { of the tomb (Fig. 9F). }\end{array}$ & N.D. & $\begin{array}{l}\text { Chroococcidiopsis sp. } \\
\text { Gloeocapsa rupestris } \\
\text { Symplocastrum friesii }\end{array}$ & N.D. \\
\hline
\end{tabular}

N.D. Not determined 

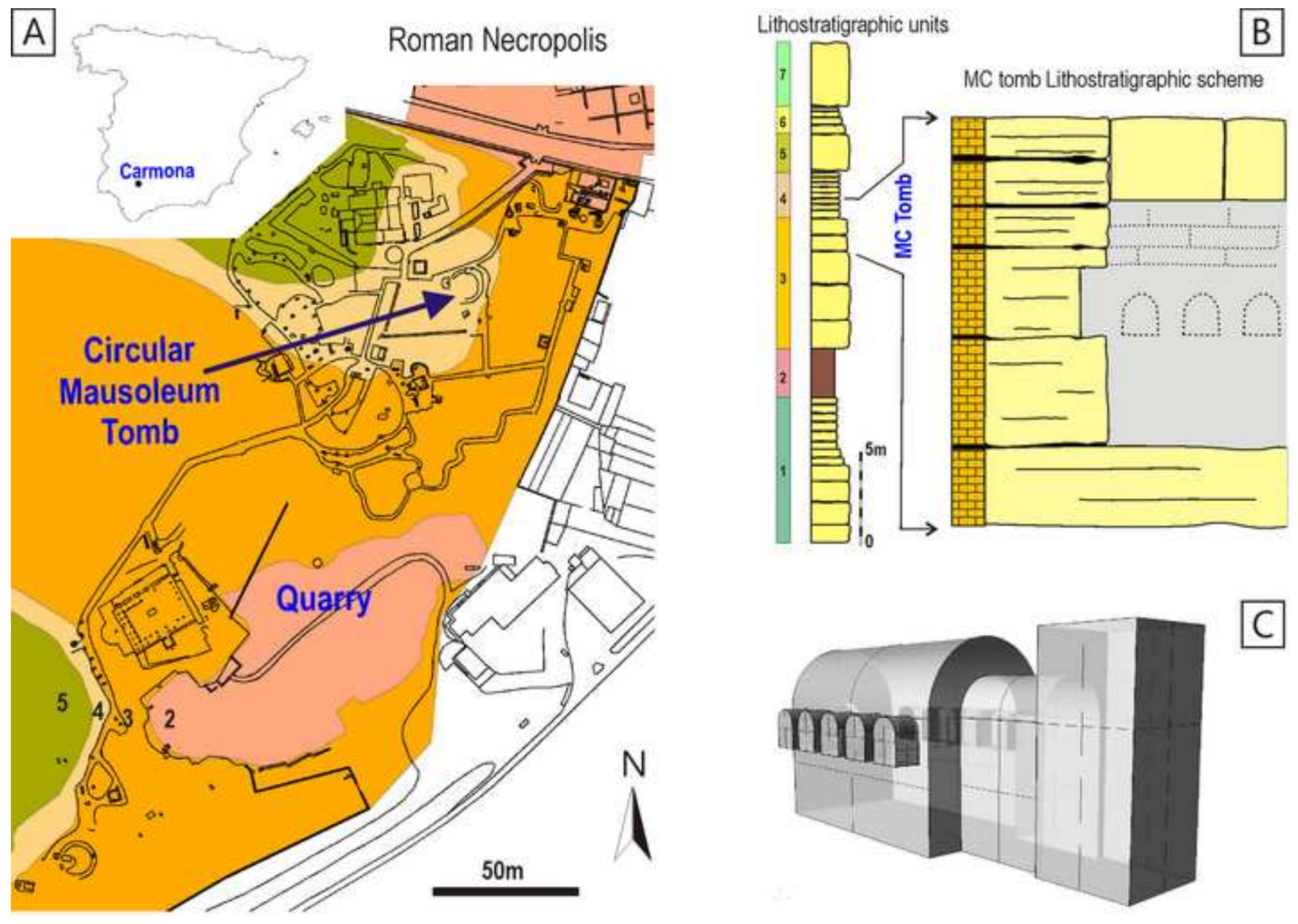


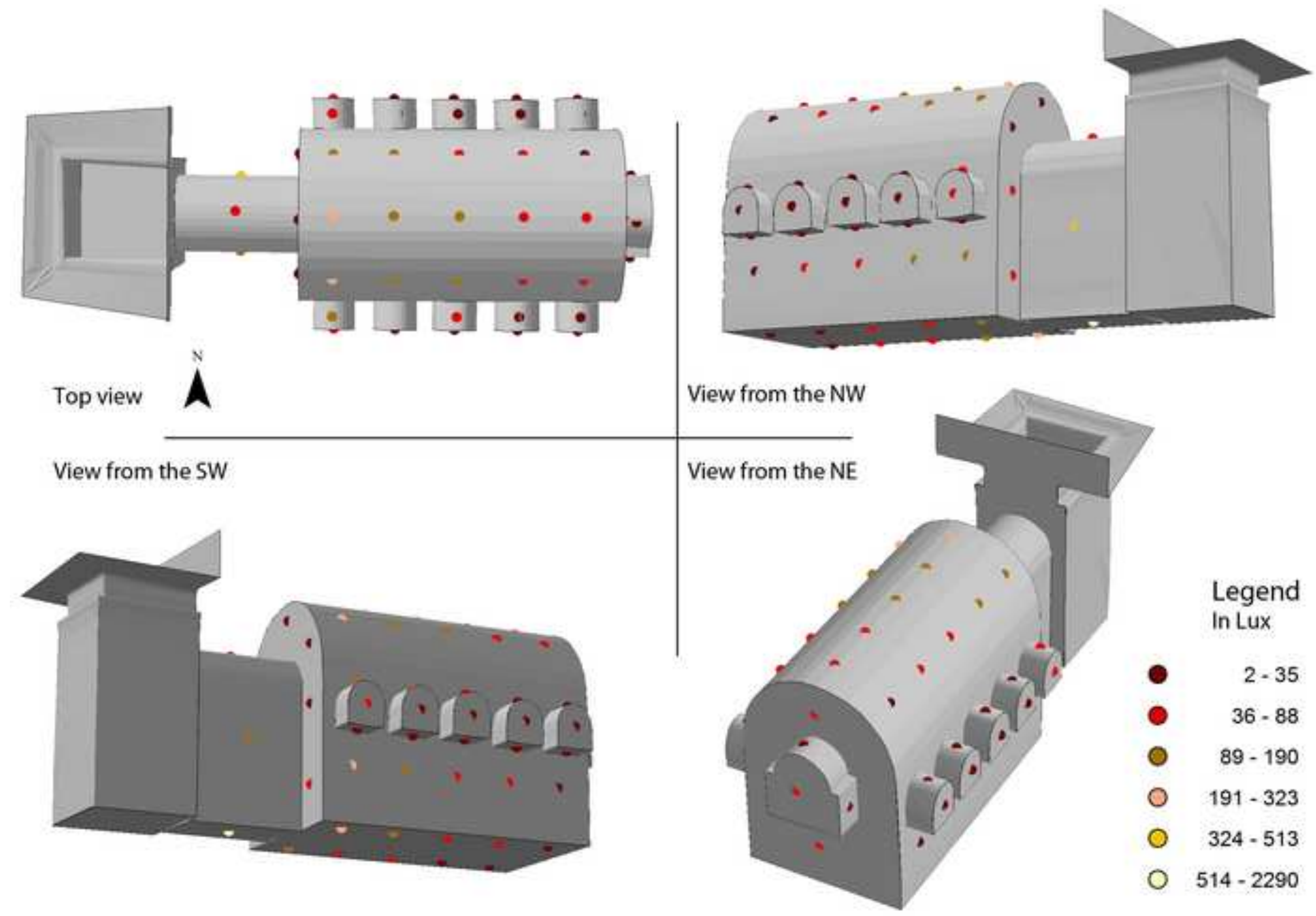

Top view

View from the SW
Legend

In Lux

- 2.35

- $89-190$

- $191-323$

- $324-513$

O $514-2290$ 
Relative humidity - tomb
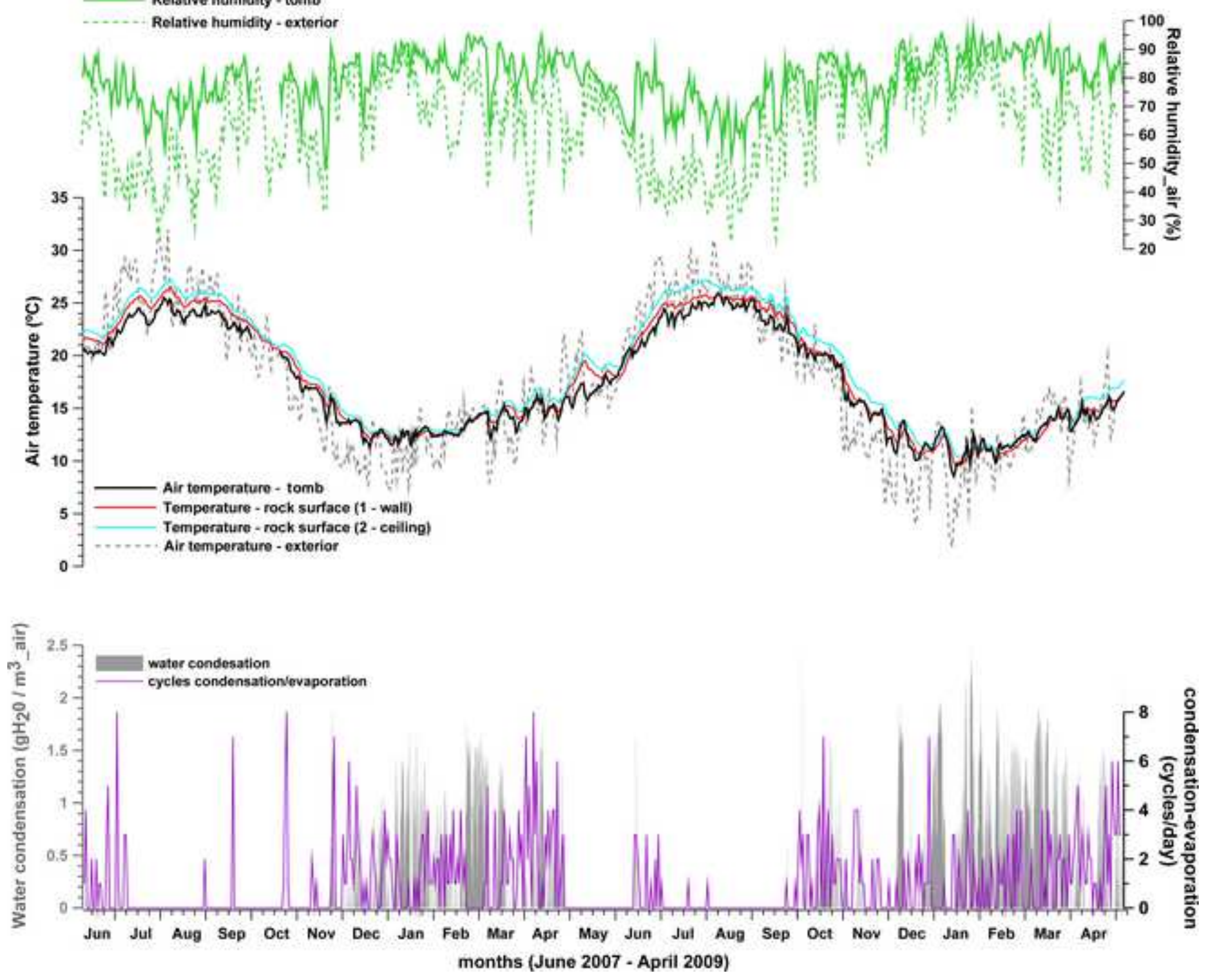
A) Hours of direct insolation

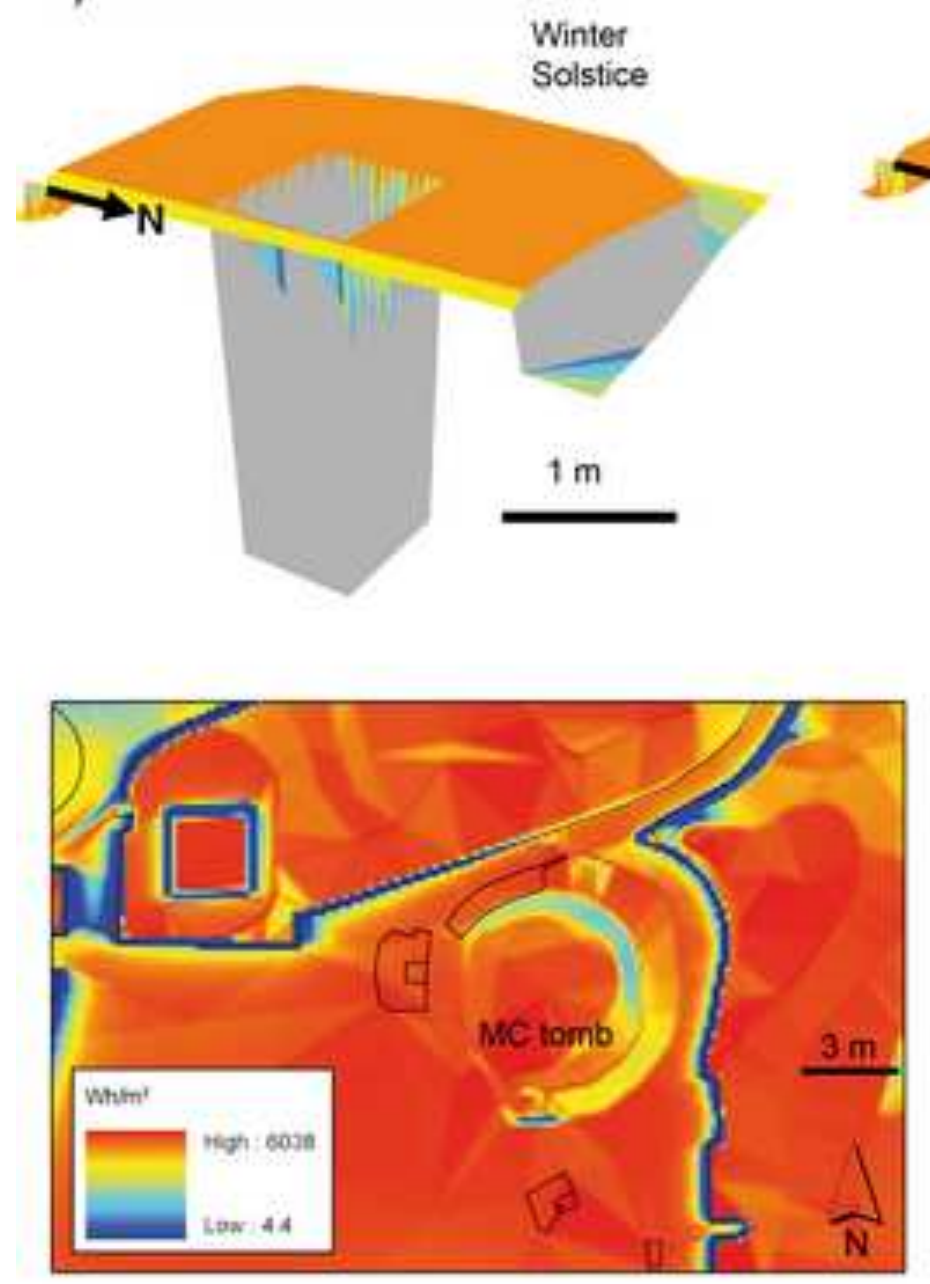

B) Amount of direct insolation in the summer solstice
Equinox
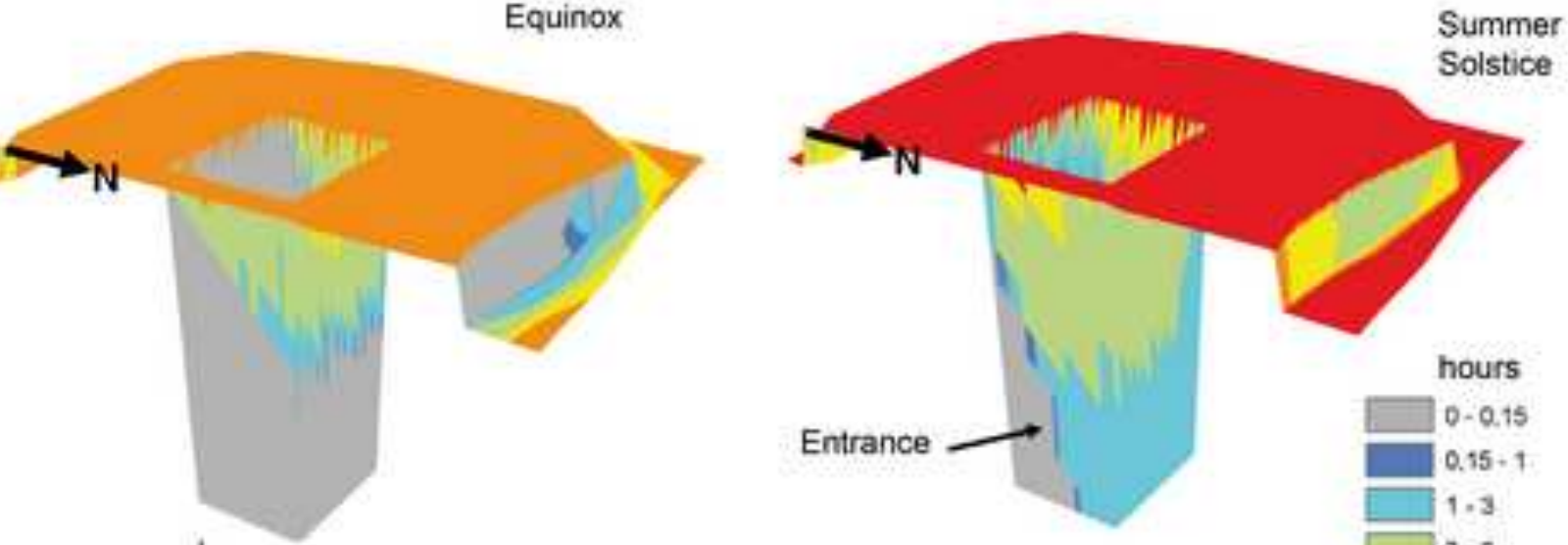

hours

Entrance

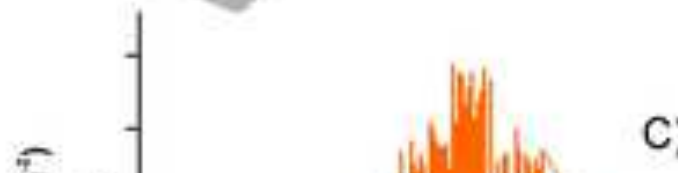

C) Measures of light intensity

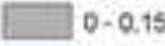

$0.15 \div 1$

1.3

ए3.0

6. 9

ए $9-12$

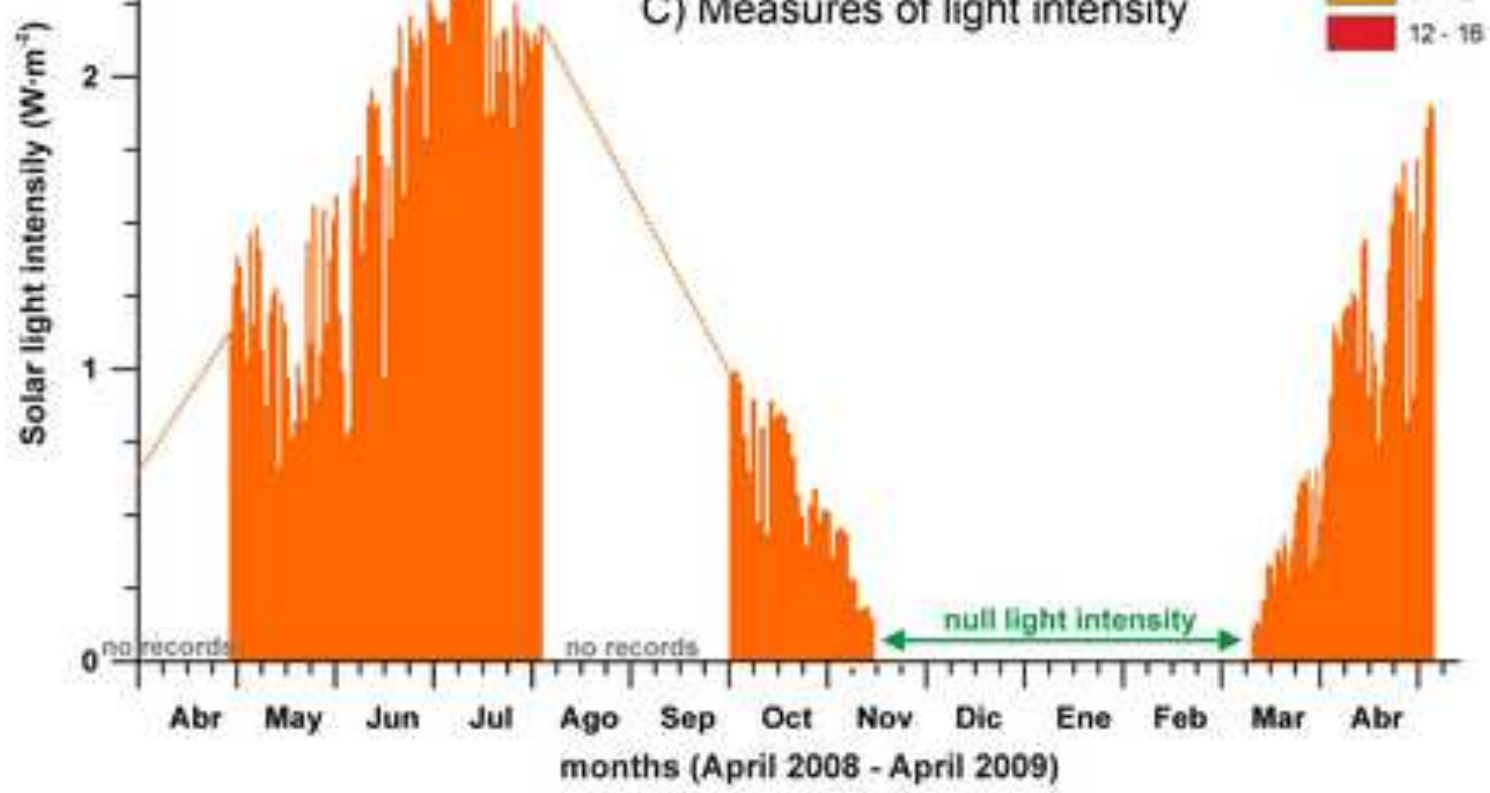




\section{Click here to download high resolution image}
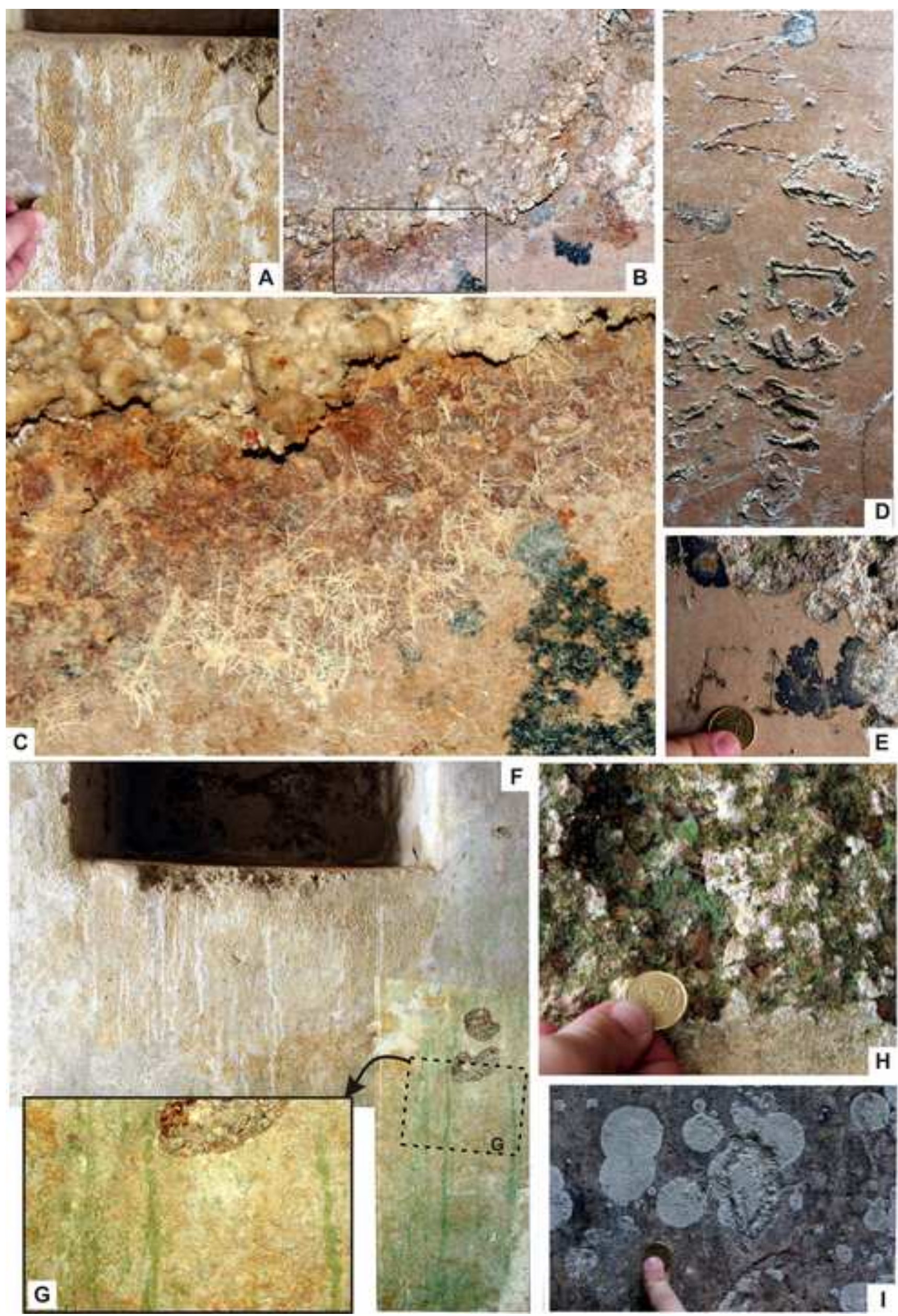


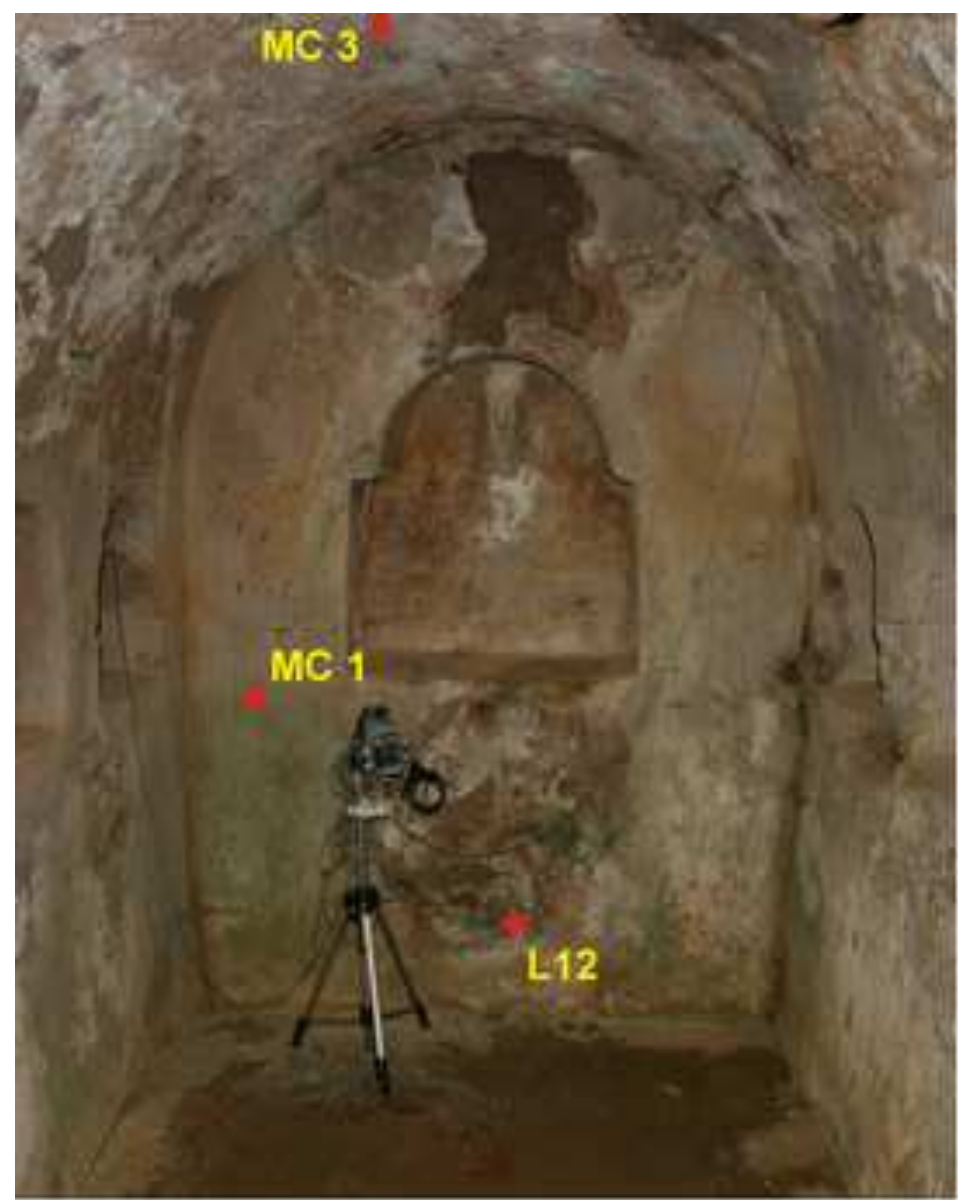

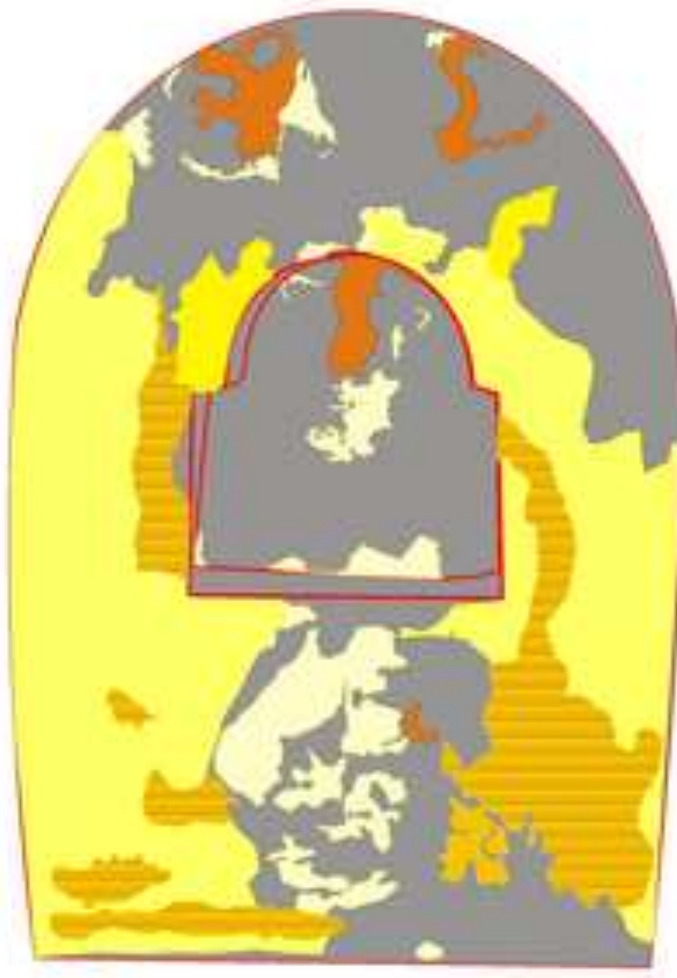

Globulitic crust

Rugose crust

Continueus smooth coating

Discontinuous smooth costing (gypsum efflocescences) Undifferentiated effloresconces

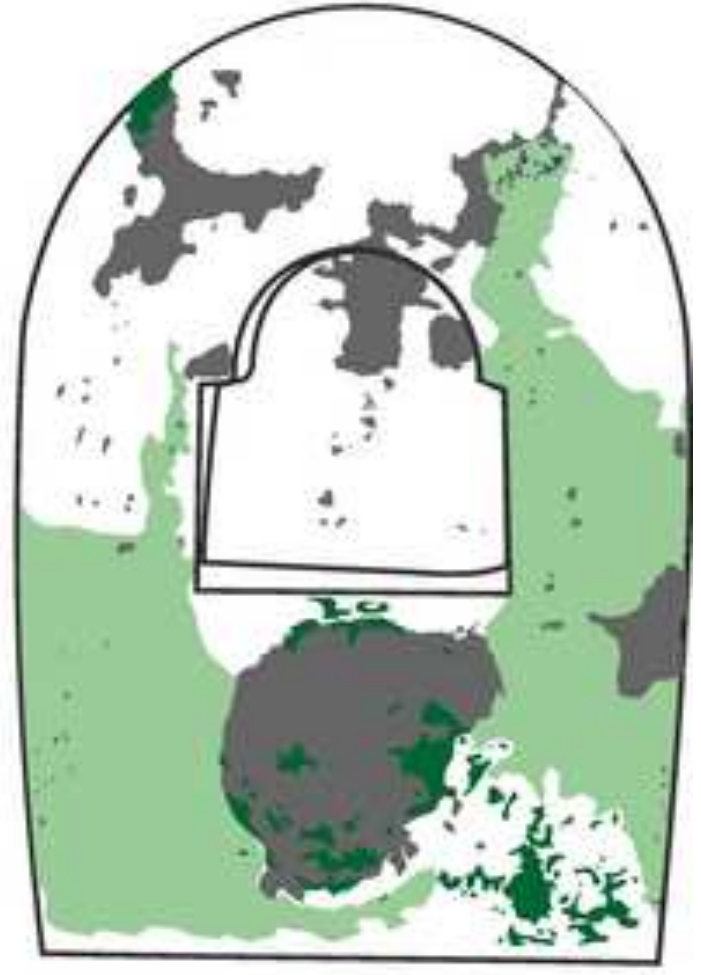

a Viotet colonies

LIighe green biofims

Dask groen biclims

Flaking, scaling, crumbling 

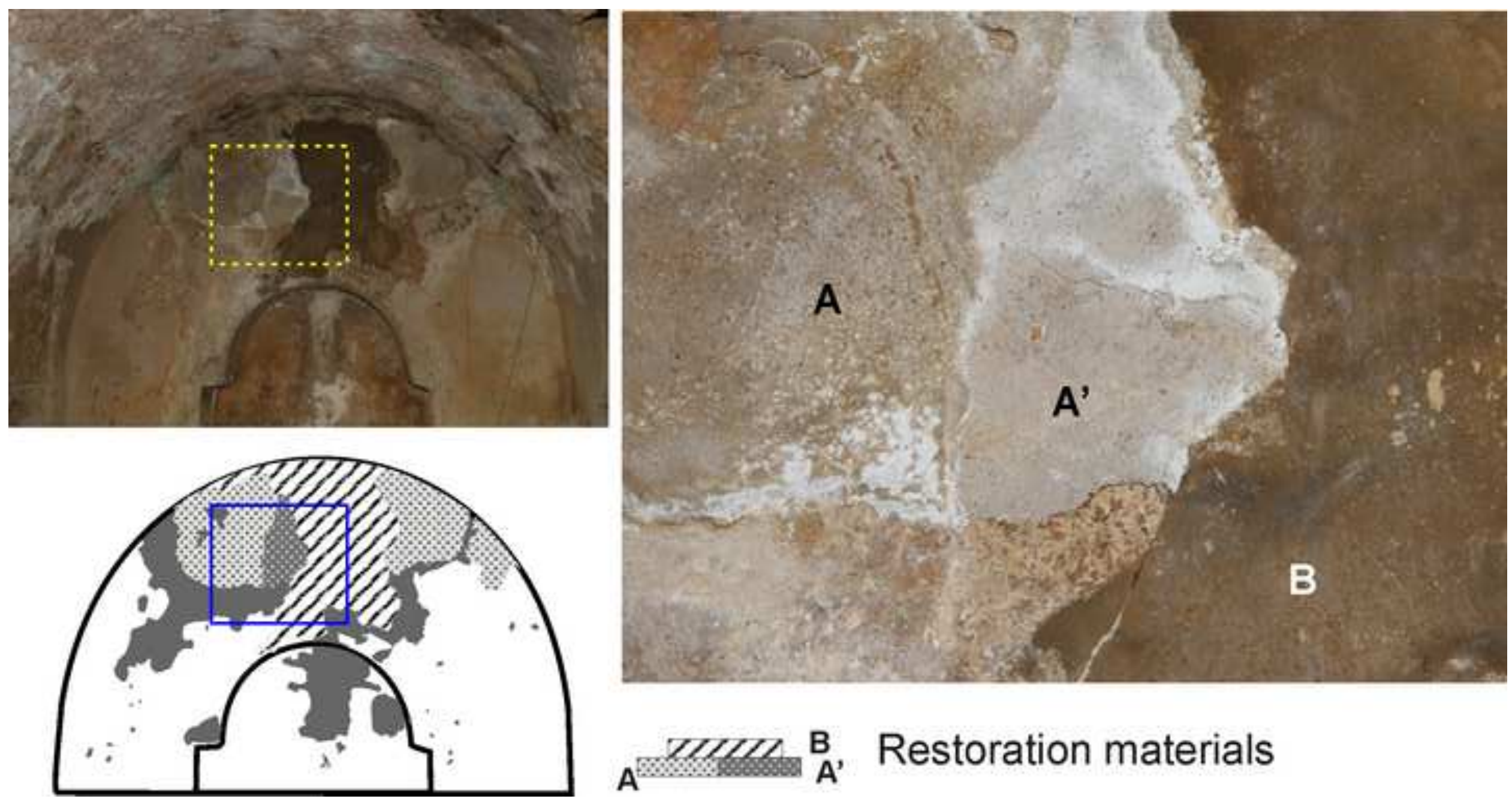

$A^{1},{ }_{A}^{B}$, Restoration materials

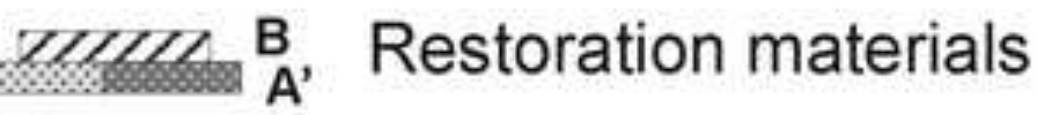


Figure

Click here to download high resolution image

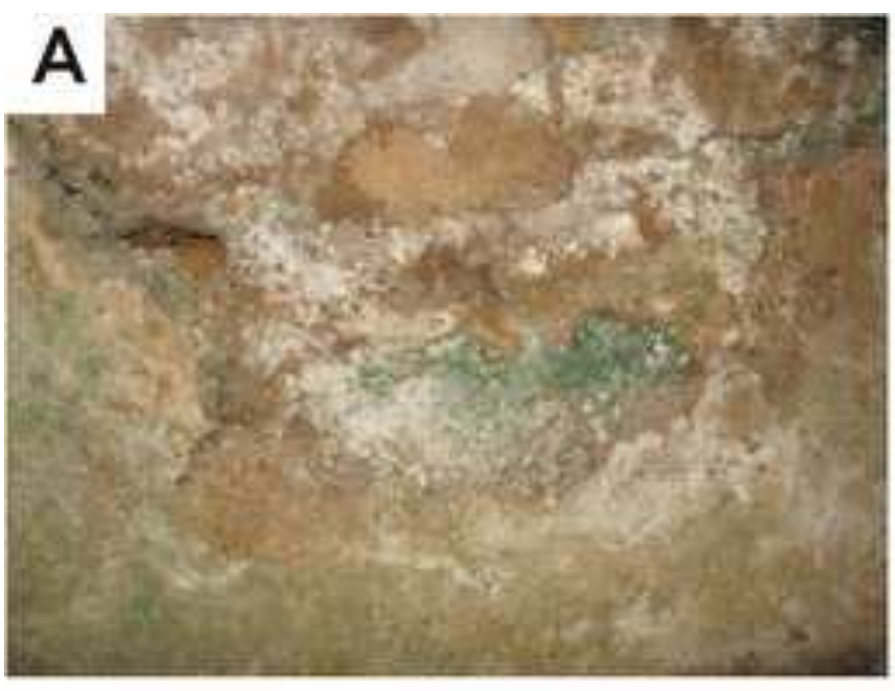

\section{B}

\section{C}
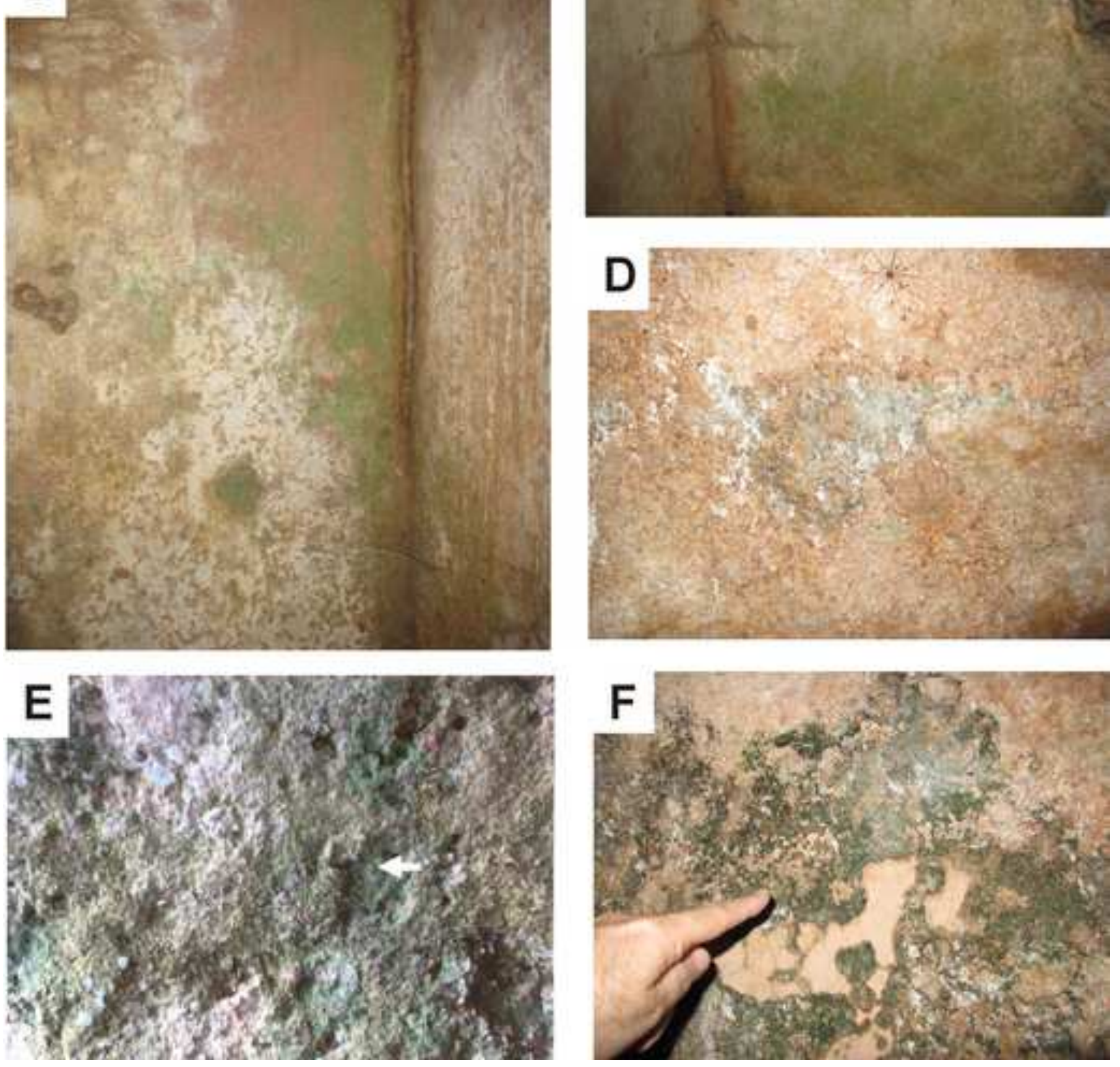


\section{Figure}

Click here to download high resolution image

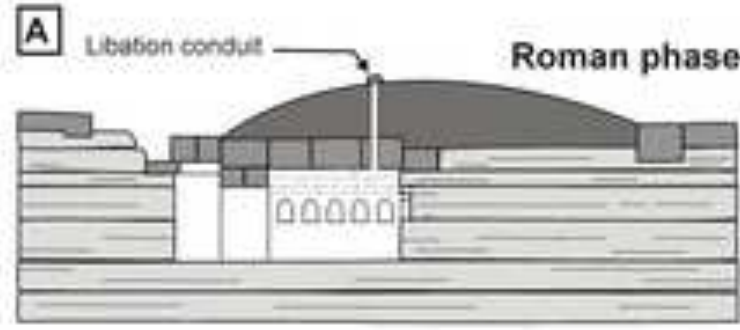

B

\section{Burial phase}

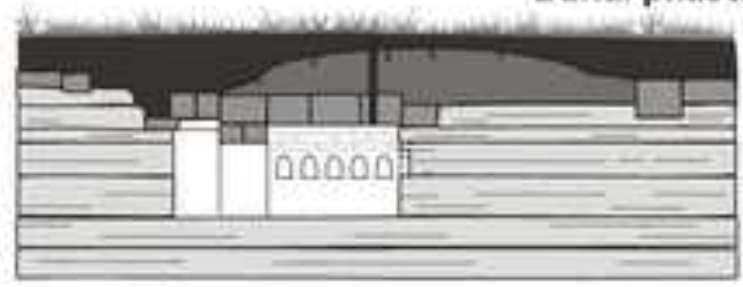

\section{c}

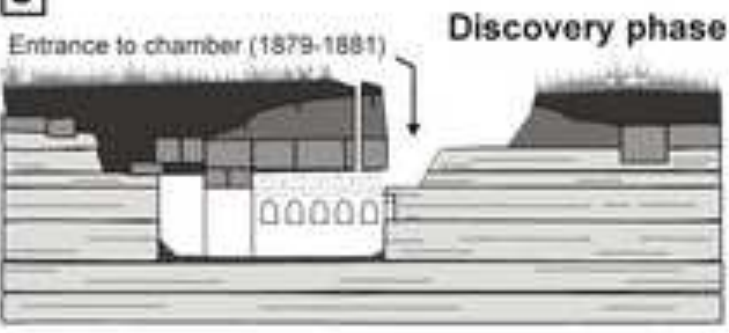

D
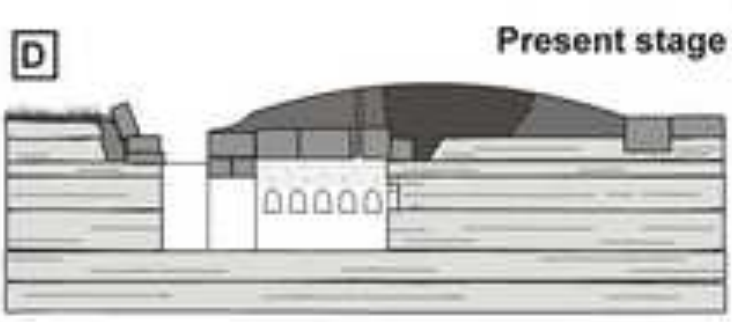

Corrective phase

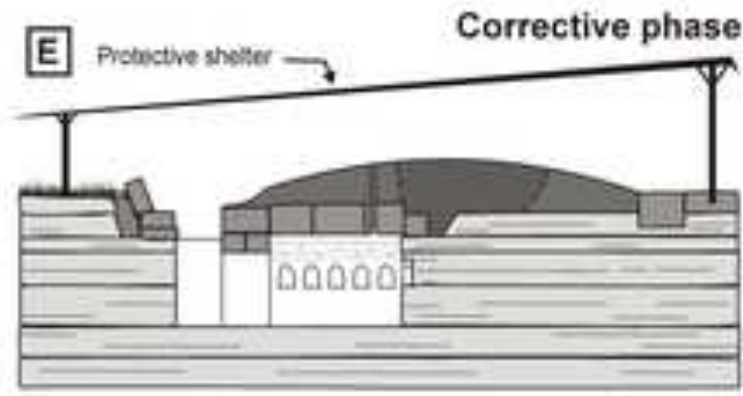

\section{$\Delta$ flooding $\Delta$ condensation \\ $\nabla$ rock/mortar temperature a air RH}
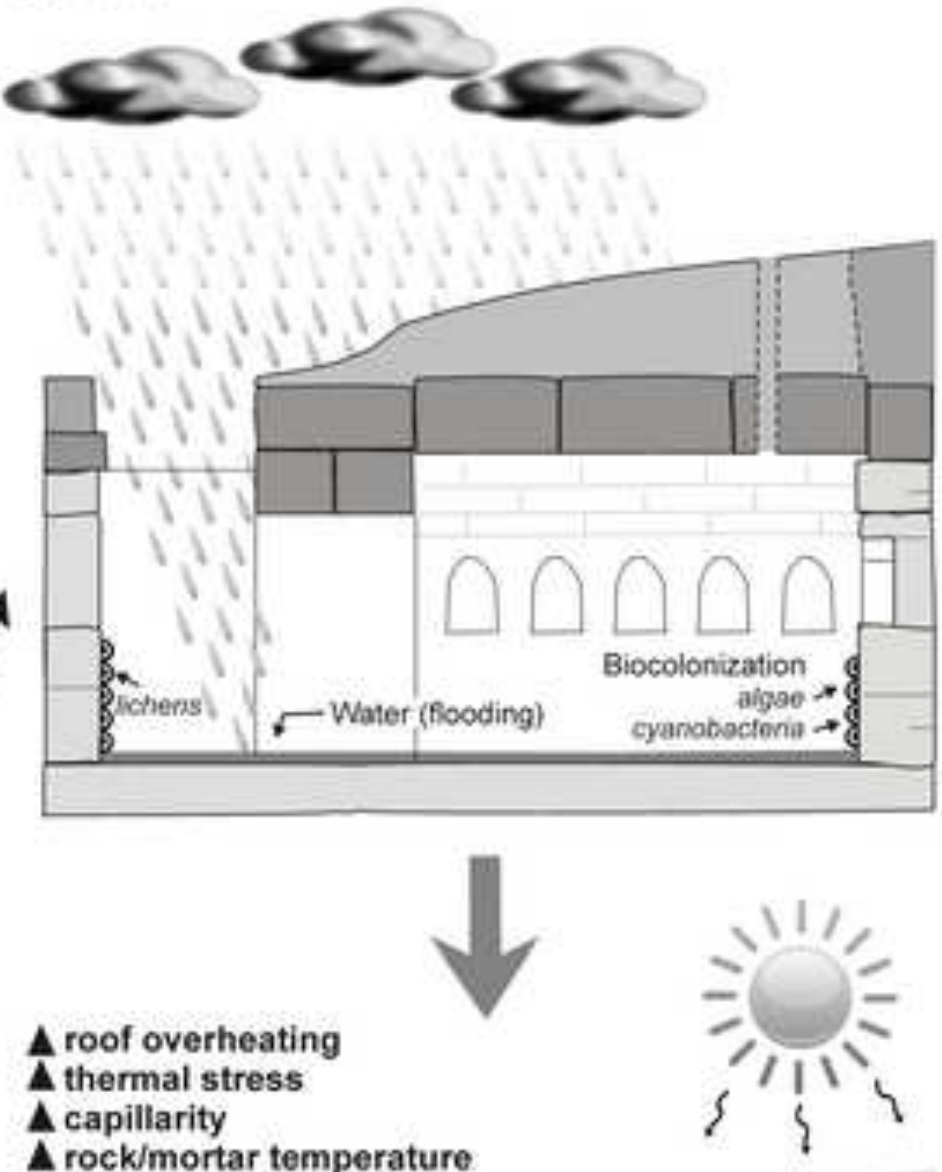

$\Delta$ rock/mortar temperature

$\nabla$ air RH

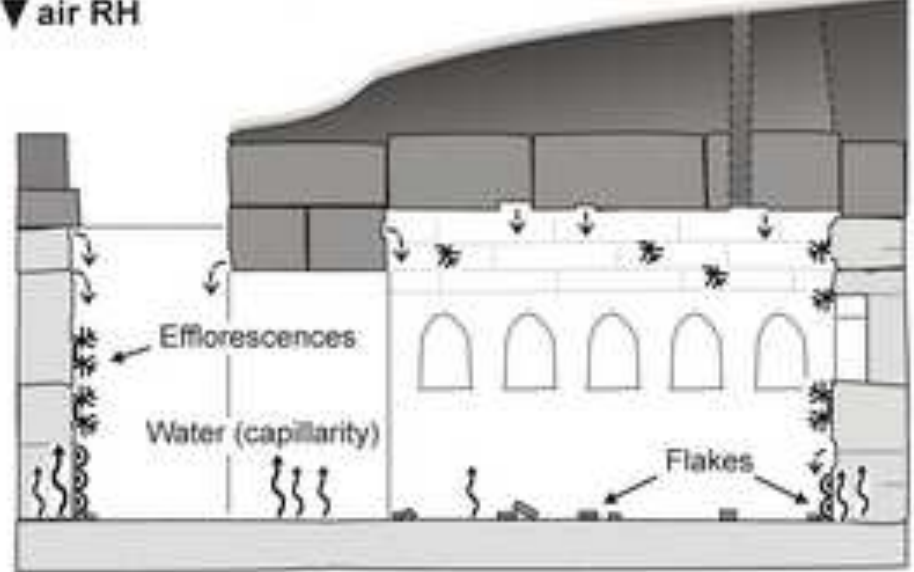

